Dicle Tıp Dergisi / Dicle Med J (2019) 46 (1) : 41 - 50

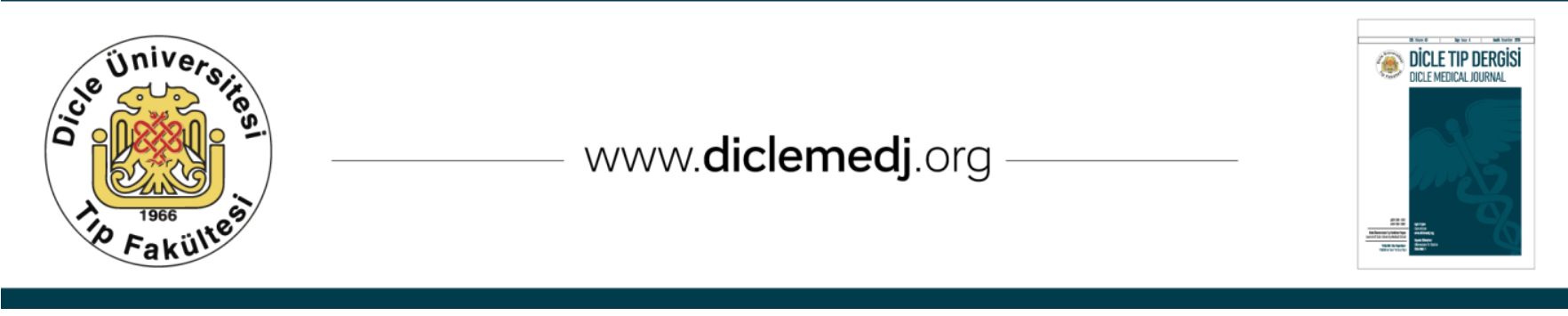

Özgün Araștırma / Original Article

\title{
Ratlarda Siklofosfamid ile İndüklenen Hepatotoksisite Üzerine Kuersetinin Etkileri
}

\author{
Semin Gedikli' ${ }^{1}$, Emin Şengül ${ }^{2}$ \\ 1 Atatürk Üniversitesi, Veteriner Fakültesi, Histoloji ve Embriyoloji AD., Erzurum, Türkiye ORCID: 0000-0001-8238-7226 \\ 2 Atatürk Üniversitesi, Veteriner Fakültesi, Fizyoloji AD., Erzurum, Türkiye ORCID: 0000-0001-8238-7226
}

Geliş: 31.05.2018; Revizyon: 07.10.2018; Kabul Tarihi: 16.10.2018

\section{Öz}

Amaç: Siklofosfamid (CYP), karaciğer ve akciğer gibi birçok organda toksisiteye neden olur. Pek çok çalışmada bazı antioksidanların CYP'nin yan etkilerine karşı koruyucu etkileri olduğu gösterilmiştir. Bu çalışmada, kuersetinin histolojik ve biyokimyasal yöntemler kullanılarak sıçanlarda CYP ile indüklenen hepatotoksisite üzerindeki koruyucu etkisinin araştırılması amaçlanmıştır.

Yöntemler: Otuz Sprague-Dawley erkek sıçan 5 gruba ayrıldı. Kontrol grubuna 7 gün boyunca intragastrik olarak mısıryağı verildi. CYP grubuna 7 gün intragastrik olarak mısır yağı verildi ve 7. günde intraperitoneal olarak CYP (200 mg/kg) uygulandı. 7 gün boyunca Q50+CYP ve Q100+CYP gruplarına sırasıyla kuersetin verildi ve 7. günde tek doz CYP (200 mg/kg) uygulandı. Q100 grubuna günde $100 \mathrm{mg} / \mathrm{kg}$ dozda kuersetin verildi. 8. günde biyokimyasal ve histopatolojik incelemeler için kan örnekleri ve karaciğer dokuları alındı.

Bulgular: MDA seviyesinin kontrol grubu ile karşılaştırıldığında CYP grubunda belirgin olarak yüksek olduğunu ve kuersetin uygulaması ile azaldığını tespit ettik. SOD ve GSH düzeyleri CYP grubunda kontrol, Q50+CYP, Q100+CYP ve Q100 gruplarına göre azalmıştı. Histolojik analizlerde CYP grubunda sinüsoidal dilatasyon, mononükleer hücre infiltrasyonu ve vasküler konjesyon gözlenirken, bu dejeneratif değişikliklerin kuersetin uygulaması ile azaldığı tespit edildi. TUNEL yönteminde, CYP grubunda kontrol grubuna kıyasla fazla sayıda TUNEL pozitif hepatosit tespit edildi. Ayrıca Bax ve Caspase-3 immunpozitivitesi açısından CYP grubunda diğer gruplara oranla imünpozitiflik fazla iken, Bcl-2 immunpozitivitesi CYP grubunda diğer gruplardan daha düşüktü.

Sonuç: Elde ettiğimiz sonuçlar, kuersetinin siklofosfamidle indüklenen hepatotoksisite üzerinde koruyucu etkiye sahip olduğunu göstermektedir.

Anahtar Kelimeler: Siklofosfamid, Kuersetin,Karaciğer, Hepatotoksisite

DOI: 10.5798/dicletip.534825

Yazışma Adresi / Correspondence: Semin Gedikli, Atatürk Üniversitesi, Veteriner Fakültesi, Histoloji ve Embriyoloji AD., Erzurum, Türkiye e-mail: semingedikli@gmail.com 


\title{
The Effects Of Quercetin On Cyclophosphamide Induced Hepatotoxicity In The Rats
}

\begin{abstract}
Objective: Cyclophosphamide (CYP) causes toxicity in many organs, as liver and lung. Several studies have shown that some antioxidants have protective effects against CYP' side effects. This study aimed to investigate the protective effect of quercetin-Q on CYP-induced hepatotoxicity in rats using histological and biochemical methods.

Methods: Thirty Sprague-Dawley male rats were divided into 5 groups. Control group was given corn oil intragastrically for 7 days. CYP group was given intragastric corn oil for 7 days and CYP (200 mg/kg) was administered intraperitoneally on the 7th day. For 7 days, Q50+CYP and Q100+CYP groups were given quercetin and single dose CYP $(200 \mathrm{mg} / \mathrm{kg})$ was administered on the 7 th day. Q100 group was given quercetin $100 \mathrm{mg} / \mathrm{kg}$ dose per day. On the 8th day, blood samples and liver tissues were taken for biochemical and histopathological examinations.

Results: When MDA level was compared with the control group, it was higher in the CYP group and decreased with the administration of quercetin. SOD and GSH levels were lower in the CYP group compared to the other groups. Histological analysis revealed that sinusoidal dilatation and mononuclear cell infiltration were observed in the CYP group, and these degenerative changes were reduced by quercetin administration. In the TUNEL method, a large number of TUNEL positive hepatocytes were detected in the CYP group. Bcl-2 immunopositivities were lower in the CYP group, while Bax and Caspase-3 immunopositivities were higher in the CYP group than other groups.
\end{abstract}

Conclusion: Our results show that quercetin has protective effect on cyclophosphamide-induced hepatotoxicity.

Keywords: Cyclophosphamide, Quercetin, Liver, Hepatotoxicity

\section{GİRIŞ}

Dünya genelinde en ölümcül hastalıklardan biri olarak kabul edilen kanser hastalığının tedavisinde tercih edilen yol genellikle kemoterapötik ilaçların kullanımıdır ${ }^{1}$. Siklofosfamit de (Cyclophosphamide-CYP) neoplastik ve otoimmün hastalıkların tedavisinde yaygın olarak kullanılan, alkilleyici bir ajandır ${ }^{2,3}$. Çeşitli kanser türlerinin tedavisinde kullanılmasının yanı sıra sistemik lupus eritematozus, romatoid artrit ve multipl skleroz gibi hastalıkların tedavisinde de yoğun bir şekilde kullanılmaktadır ${ }^{4}$. CYP gibi antikanserojenik ilaçlar terapötik etkiye sahip olmanın yanı sıra, normal dokular üzerinde de toksik etki göstermektedir ve bu durum kullanım alanlarını kısıtlamaktadır ${ }^{2,4}$. CYP'nin tedavi edici etkisinin dişında idrar kesesinde akut inflamasyon, renal hasar ${ }^{5}$, kemik iliği baskılanması, bulantı, kusma, ürotoksisite, kardiyotoksisite, immünotoksisite ${ }^{1,6}$ ve özellikle de hepatotoksisite gibi pek çok yan etkisinin olduğunu gösteren çalışmalar mevcuttur ${ }^{7-10}$.
Kanser kemoterapisinde bir ön ilaç olarak kullanılan CYP, karaciğerde sitokrom P450 enzim ailesinin üyeleri olan CYP3A4 ve CYP2B6 enzimleri ile metabolize edilir. Metabolizasyon işleminin sonunda akrolein ve fosfamid hardalı olarak adlandirılan sitotoksik metabolitler oluşur ${ }^{5,11}$. Karaciğerde oluşan bu metabolitler sistemik dolaşımla farklı dokulara dağılarak oksidatif stres kaynaklı doku hasarına neden olurlar ${ }^{12,13}$. Oluşan bu oksidatif stresin, CYP ile indüklenen hepatotoksisitenin sebebi olduğunu gösteren çalışmalar da mevcuttur ${ }^{13-15}$. Hücrelerde lipid peroksidasyonunu başlatıcı bir ürün olarak tanımlanan akrolein, DNA'yı alkilleyici bir ajan olarak hareket eder ${ }^{16}$. Akrolein, glutatyon sülfidril gruplarının modifikasyonu ile hızlı bir şekilde metabolize edilir ve bu mekanizma sonucunda glutatyon seviyesindeki azalma ile hücresel oksidatif stres artışı meydana gelmiş olur ${ }^{17}$.

Son zamanlarda araştırmacılar, kemoterapi ilaçlarının antineoplastik etkilerini engellemeden normal dokular üzerindeki yan etkilerini en aza indirebilecek ve bağışıklığı 
artıracak bitki kökenli bileşikler üzerinde çalışmalar yapmaktadır ${ }^{18}$. Çeşitli çalışmalarda CYP ile indüklenen hasar üzerine bazı antioksidanların etkileri rapor edilmiştir ${ }^{19-21}$. Kemopreventif maddeler arasında, antioksidan özelliği en çok çalışılanlar flavonoidlerdir. Güçlü antioksidan özelliği bilinen bileşiklerden birisi de kuersetindir. Kuersetin çeşitli meyve ve sebzelerde bolca bulunan antioksidan, antiinflamatuvar ve anti-kanser etkili flavonoidlerden birisidir ${ }^{22,23}$.

Kuersetin, süperoksit $\left(\mathrm{O}_{2} \cdot\right)$ ve hidroksil $(\mathrm{OH} \cdot)$ gibi serbest radikalleri temizler, ksantin oksidaz ve lipid peroksidasyonunu engeller ${ }^{24}$. Bunların yanı sıra anti-diabetik, antiinflamatuar ve immün sistemi baskılama gibi pek çok farmakolojik aktiviteye de sahiptir ${ }^{25}$. Yapılan çalışmalarda kanser hücrelerinin çoğalmasını önlediği ${ }^{26,27}$, in vivo olarak da ilaca bağlı toksisite ve oksidatif stresi azaltıcl etki gösterdiği tespit edilmiştir28,29.

Biz de tüm bu literatür bilgileri doğrultusunda ratlarda CYP ile oluşturulan hepatotoksisite üzerine kuersetinin etkilerini biyokimyasal ve histopatolojik olarak göstermeyi hedefledik.

\section{YÖNTEMLER}

Bu çalışma, Atatürk Üniversitesi Tıbbi Deneysel Araştırma ve Uygulama Merkezi ile Atatürk Üniversitesi Veteriner Fakültesi Biyokimya ve Histoloji-Embriyoloji Anabilim Dalı Laboratuvarlarında gerçekleştirilmiştir. Ayrıca çalışmamız, Atatürk Üniversitesi Rektörlüğü Hayvan Deneyleri Yerel Etik Kurulu'nun 2015/90 No'lu kararı ile onaylanmış ve Atatürk Üniversitesi BAP birimi tarafından 2015/62 No'lu Kapsamlı Araştırma Projesi kapsamında desteklenmiștir.

\section{Deney Hayvanları}

Çalışmada, ortalama 250-300 gr ağırlığında, 1012 haftalık, yetişkin 30 adet Sprague Dawley cinsi erkek rat kullanıldı. Standart bakım ve beslenme koşullarına tabi tutulan ratlar, her grupta 6 hayvan olacak şekilde 5 gruba ayrıldı ve gruplar aşağıda belirtildiği gibi oluşturuldu:

\begin{tabular}{llc}
\hline Gruplar & Grup isimleri & Hayvan sayısı \\
\hline Grup 1 & Kontrol Grubu & 6 \\
Grup 2 & CYP Grubu & 6 \\
Grup 3 & Q50+CYP Grubu & 6 \\
Grup 4 & Q100+CYP Grubu & 6 \\
Grup 5 & Q100 Grubu & 6 \\
\hline
\end{tabular}

$\mathrm{Bu}$ gruplardan kontrol grubuna deney süresince (7 gün boyunca) gavaj yoluyla mısır yağı verildi. Grup 2'deki ratlara 7 gün boyunca gavajla mısır yağı verildi ve deneyin 7 . günü mısır yağı verildikten sonra tek doz CYP (200 $\mathrm{mg} / \mathrm{kg}$ ) uygulandı. Grup 3'teki sıçanlara deney süresince mısır yağında çözünmüş haldeki kuersetin gavaj yoluyla $50 \mathrm{mg} / \mathrm{kg}$ oranıla uygulandı ve 7. gün kuersetin uygulamasından sonra tek doz CYP $(200 \mathrm{mg} / \mathrm{kg})$ verildi. Grup 4'teki hayvanlara 7 gün boyunca gavajla mısır yağında çözünmüş haldeki kuersetin 100 $\mathrm{mg} / \mathrm{kg}$ oranıyla uygulandı ve 7 . gün kuersetin uygulamasindan sonra tek doz CYP (200 $\mathrm{mg} / \mathrm{kg}$ ) uygulandı. Grup 5'e ise 7 gün boyunca $100 \mathrm{mg} / \mathrm{kg}$ oranında kuersetin mısır yağında çözdürülmüş şekilde gavajla verildi. Deneyin 8. günü (CYP uygulamasından 24 saat sonra) tüm sıçanlar tiopental sodyum $(20 \mathrm{mg} / \mathrm{kg})$ ile anesteziye alındı ve servikal dislokasyon metodu ile sakrifiye edildiler. Hayvanlardan alınan karaciğer dokularının bir kısmı biyokimyasal analizler için $-80{ }^{\circ} \mathrm{C}$ dondurucuya konuldu. Karaciğer dokularının bir bölümü ise histopatolojik incelemeler için formaldehit içine alındı.

\section{Biyokimyasal Analizler}

Deney sonunda sakrifiye edilen ratlardan alınan karaciğer dokularında oksidan ve antioksidan parametrelerden malondialdehit (MDA, CAYMAN-10009055), superoksit dismutaz (SOD, CAYMAN-706006) ve glutatyon 
(GSH, CAYMAN-703002)parametreleri Elisa kitleri (Cayman Chemical

Company, Ann Arbor, MI, USA) aracılığıyla analiz edildi.

\section{Histopatolojik Analizler}

Çalışmanın sonunda anestezi altında sakrifiye edilen sıçanlardan alınan karaciğer dokuları histopatolojik açıdan değerlendirilmek üzere $\% 10$ 'luk nötral tamponlu formaldehit içine konuldu. Doku örnekleri ksilol ve alkol serilerinden geçirildikten sonra parafine gömüldü. Parafin blokları Leica RM2125RT mikrotomu (Leica Microsystems, Wetzlar, Germany) ile $5 \mu \mathrm{m}$ kalınlığında kesildi. Bütün gruplara ait kesitler histopatolojik değerlendirmelerinin yapılabilmesi için Crossman'ın modifiye üçlü boyaması ile boyandı. İmmuno-histokimyasal incelemeler için de kesitlere anti-Caspase-3 (Abcam,ab13847), anti-Bcl-2 (Abcam,ab196495), anti-Bax (Abcam,ab53154) ve TUNEL (In Situ Cell Death Detection Kit, POD; 11684817910 Roche) metotları uygulandı. Tüm boyamalara ait lamların ışı mikroskobu altında (Nikon Eclipse i50, Tokyo, Japan) incelemesi yapılarak, kesitlerin fotoğrafları çekildi.

\section{İstatistiksel Analiz}

Çalışmanın sonunda elde edilen değerler istatistik veri programı yardımıyla ikiden fazla bağımsız grupların istatistiksel analizinde kullanılan one-way ANOVA sonrası Duncan testi uygulanarak değerlendirildi. $\mathrm{P}<0.05$ değeri anlamlı olarak kabul edildi.

\section{BULGULAR}

\section{Biyokimyasal Bulgular}

Karaciğer dokusunda yapılan biyokimyasal analizler sonuçlarına göre CYP grubunda, SOD ve GSH aktivitesinin kontrol grubundan düşük olduğu MDA seviyesinin ise yüksek olduğu belirlendi. $\mathrm{Bu}$ sonuçlar istatistiksel olarak anlamliydı. Q50+CYP grubunda ve Q100+CYP gruplarında SOD ve GSH seviyesi CYP grubuna oranla artış göstermekteydi, ancak Q100+CYP grubundaki artış istatistiksel açıdan anlamlıydı. MDA seviyesi ise CYP grubuna oranla kuersetin uygulanan gruplarda azalma göstermekle birlikte Q100+CYP ve Q100 gruplarında anlam içeriyordu. Sonuçlar Tablo 1'de belirtilmiştir.

Tablo 1. Deney gruplarından elde edilen SOD, GSH ve MDA enzim seviyeleri

\begin{tabular}{|l|c|c|c|}
\hline Gruplar & SOD & GSH & MDA \\
\hline Kontrol & $23,74 \pm 0,76^{\mathrm{a}}$ & $12,75 \pm 1,44^{\mathrm{a}}$ & $1,73 \pm 0,32^{\mathrm{a}}$ \\
\hline CYP & $21,32 \pm 1,31^{\mathrm{b}}$ & $6,98 \pm 0,08^{\mathrm{b}}$ & $2,13 \pm 0,56^{\mathrm{b}}$ \\
\hline Q50+CYP & $22,74 \pm 1,17^{\mathrm{b}}$ & $7,56 \pm 1,51^{\mathrm{b}}$ & $2,08 \pm 0,47^{\mathrm{b}}$ \\
\hline Q100+CYP & $26,07 \pm 1,39^{\mathrm{c}}$ & $9,88 \pm 1,38^{\mathrm{c}}$ & $2,05 \pm 0,35^{\mathrm{c}}$ \\
\hline Q100 & $24,94 \pm 1,38^{\mathrm{a}}$ & $10,05 \pm 1,35^{\mathrm{a}}$ & $2,02 \pm 0,33^{\mathrm{c}}$ \\
\hline
\end{tabular}

Aynı satırdaki harfler, değerler arasındaki istatistiksel fark göstermektedir. Aynı harf ile gösterilen değerler arasında istatistiksel fark yoktur. İstatistiksel analizler SPSS 17.0 programı One-way Anova (Duncan Post-Hoc Test) metoduyla yapılmıştır. $p<0,05$ olarak kabul edilmiştir.

\section{Histopatolojik Bulgular}

Kontrol grubuna ait Crossman'ın modifiye üçlü boyaması ile boyanan karaciğer kesitleri incelendiğinde, dokunun normal bir histolojik yapıya ve morfolojiye sahip olduğu gözlendi (Şekil 1A). Ancak CYP grubuna ait karaciğer kesitlerinde sinüzoidal dilatasyon, mononükleer hücre infiltrasyonu, vasküler konjesyon tespit edildi (Şekil 1B). Gözlemlenen bu yapisal hasarlar ise Q50+CYP grubunda azalmış, Q100+CYP grubunda ise kontrol grubuna yakın bir histolojik yapıya dönüşmüştü (Şekil 1C,D).

Apoptozisi göstermek için yapılan TUNEL boyamada, kontrol grubunda az sayıda hepatositin pozitif olduğu, CYP grubunda ise özellikle periasiner bölgede çok sayıda pozitif hücrenin varlığı tespit edildi (Şekil $1 \mathrm{~F}, \mathrm{G}$ ). Q50+CYP ve Q100+CYP gruplarında ise kuersetin miktarındaki artışa oranla daha fazla düzelmenin olduğu, yani CYP grubuna oranla daha az pozitif hücre sayısının olduğu gözlendi 
(Şekil 1H,I). Q100 grubundaki immunpozitiflik ise kontrol grubuna yakın düzeydeydi(Şekil 1J).

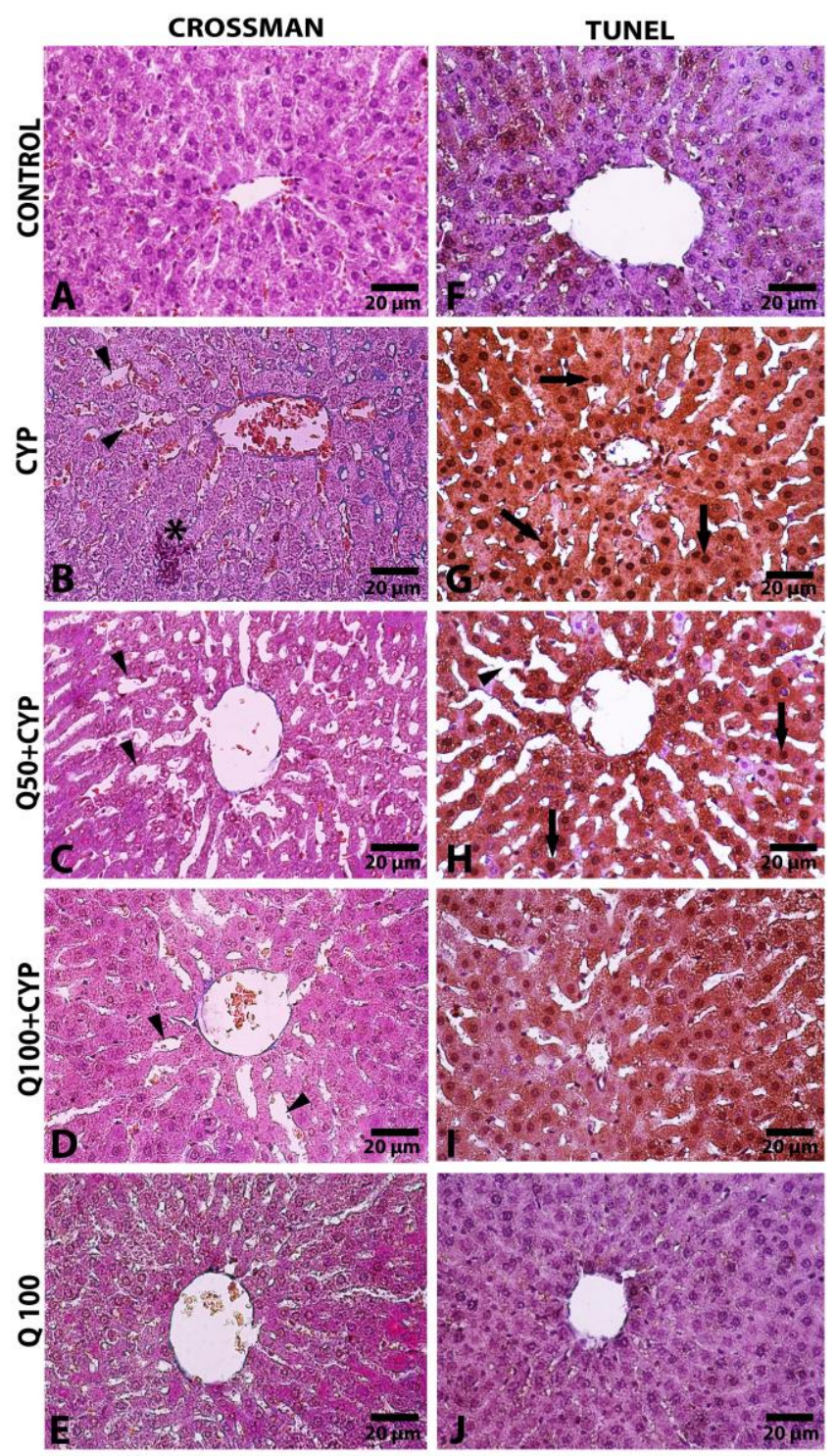

Şekil 1: A: Kontrol, B: CYP, C: Q50+CYP, D: Q100+CYP, E: Q100 grubu sıçanlara ait karaciğer kesitlerinin 1ş1k mikroskobik görüntüleri. ok baş1: sinüzoidal dilatasyon, yıldı: mononükleer hücre infiltrasyonu, Boya: Crossman'ın Üçlü Boyaması, Bar: 20 $\mu \mathrm{m}$.

F: Kontrol, G: CYP, H: Q50+CYP, I: Q100+CYP, J: Q100 grubu sıçanlara ait karaciğer kesitlerinde TUNEL yöntemiyle apoptotik hücrelerin gösterilmesi. ok: apoptotik hücreler. TUNEL metodu, Bar: $20 \mu \mathrm{m}$.
Karaciğer kesitlerine Caspase-3, Bax ve Bcl-2 antikorları ile yapılan immunohistokimyasal boyama sonuçlarına göre; Caspase-3 immünreaktivitesinin CYP grubunda kontrol grubuna oranla oldukça arttığı, kuersetin tedavisi uygulanan gruplarda ise kuersetindeki doz artışına bağlı olarak Caspase-3 immünpozitifliğinin azaldığı tespit edildi. Negatif kontrol grubunda ise herhangi bir boyanma saptanmadı (Şekil 2). Kesitlere uygulanan Bax boyama sonuçları da Caspase-3 immünreaktivite sonuçları ile paralellik göstermekteydi (Şekil 3). Anti-apoptotik proteinler ailesinden olan Bcl-2 immünpozitifliği bakımından kesitler değerlendirildiğinde ise kontrol grubundaki pozitif hücre sayısının başta CYP grubu olmak üzere diğer tüm deney gruplarından fazla olduğu tespit edildi (Şekil 4).

\section{TARTIŞMA}

Kanser kemoterapisinde kullanılan, alkilleyici bir ajan olan CYP'nin birçok yan etkisi olduğu bilinmektedir. Toksik etkiye sahip olması ise, metabolitlerinden biri olan akrolein üretimi ile alakalıdır ${ }^{30,31}$. Akrolein $\alpha, \beta$-doymamış bir aldehittir ve oldukça reaktif olan bu bileşik lipid peroksidasyonunun bir göstergesi olarak tanımlanır ${ }^{32}$. CYP tedavisi ile ortaya çıkan hepatotoksisitenin nedeninin serbest radikallerin aşırı üretimi ile indüklenen oksidatif stres olduğu bildirilmektedir ${ }^{33}$. Vücutta antioksidanlar ve oksidanlar arasında var olan dengenin oksidan sistem lehine bozulması sonucunda oluşan oksidatif streste, lipid peroksidasyonunun meydana gelmesi ve serbest radikallerin açığa çıkması sonucu organizmada hücresel hasar oluşur. Organizmada var olan antioksidan mekanizmalar oksidatif strese karşı organizmayı korumakta yetersiz kalırsa, hücrelerin fonksiyonlarında aksamalar meydana gelir ${ }^{34}$. 


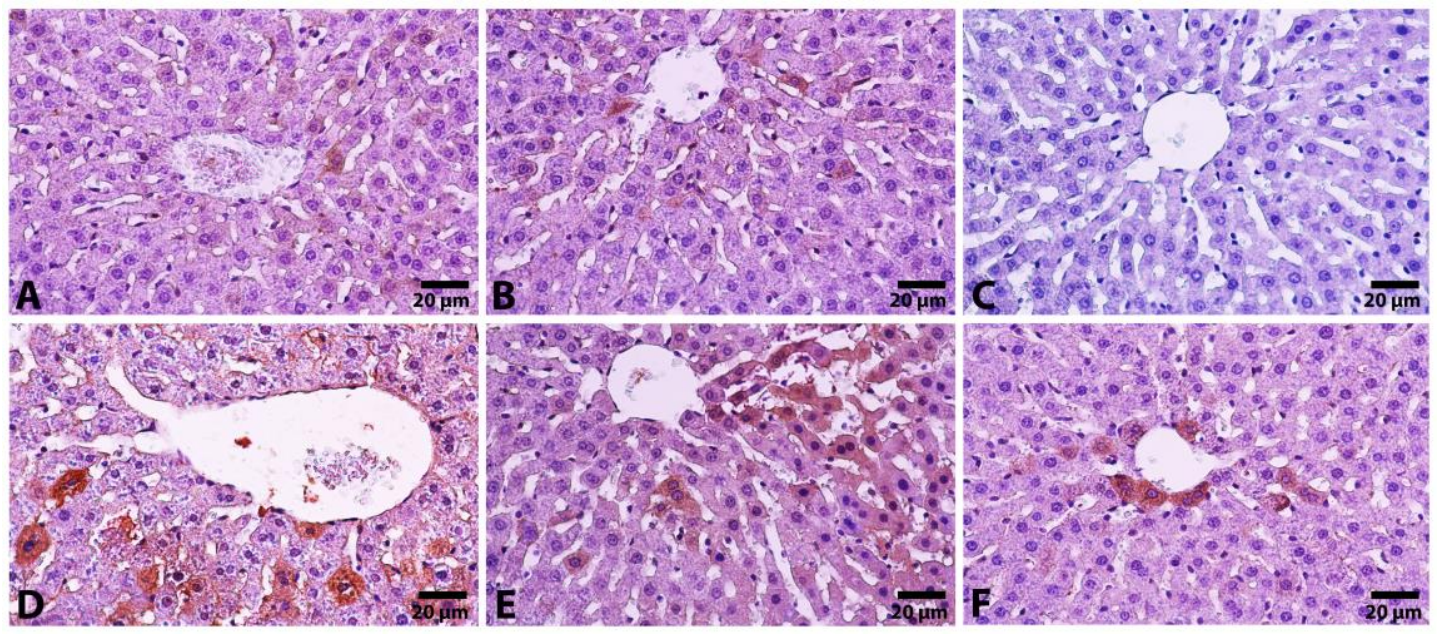

Şekil 2: A: Kontrol, B: Q100, C: Negatif Kontrol, D: CYP, E: Q50+CYP, F: Q100+CYP grubu siçanlara ait karaciğer kesitlerinde Caspase-3 immünpozitifliği. Bar: $20 \mu \mathrm{m}$.

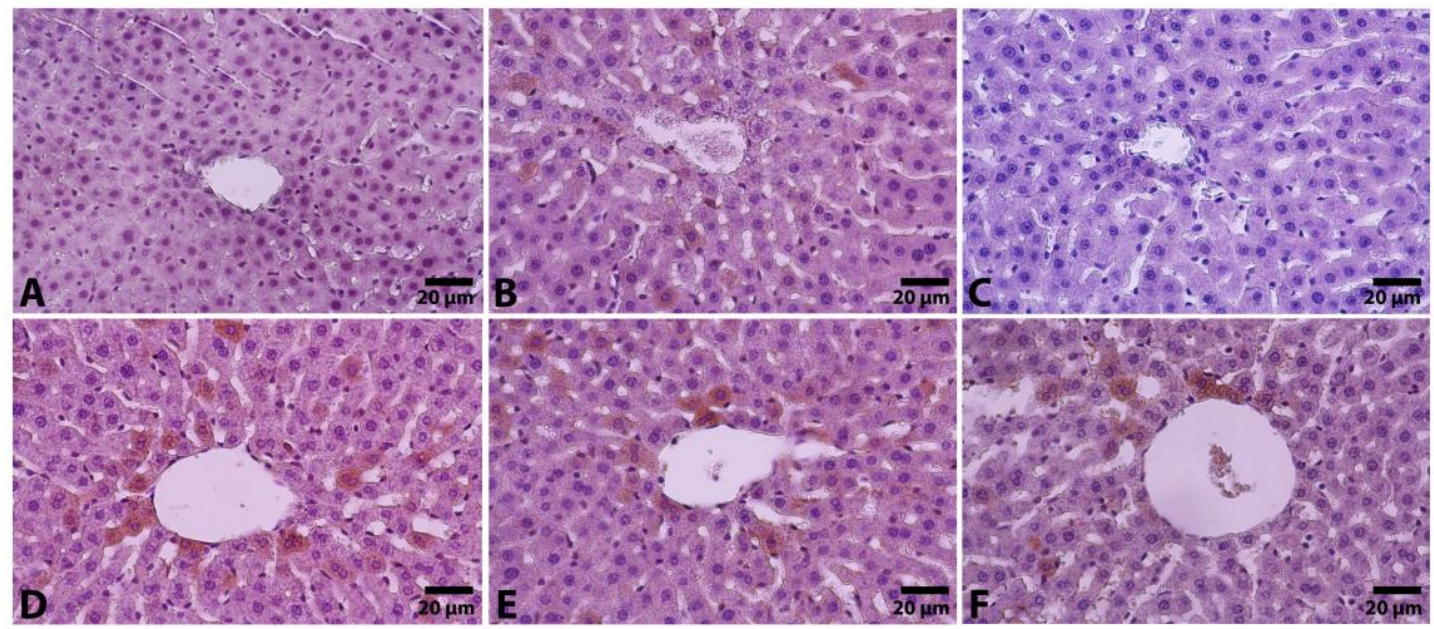

Şekil 3: A: Kontrol, B: Q100, C: Negatif Kontrol, D: CYP, E: Q50+CYP, F: Q100+CYP grubu sıçanlara ait karaciğer kesitlerinde Bax immünpozitifliği. Bar: $20 \mu \mathrm{m}$.
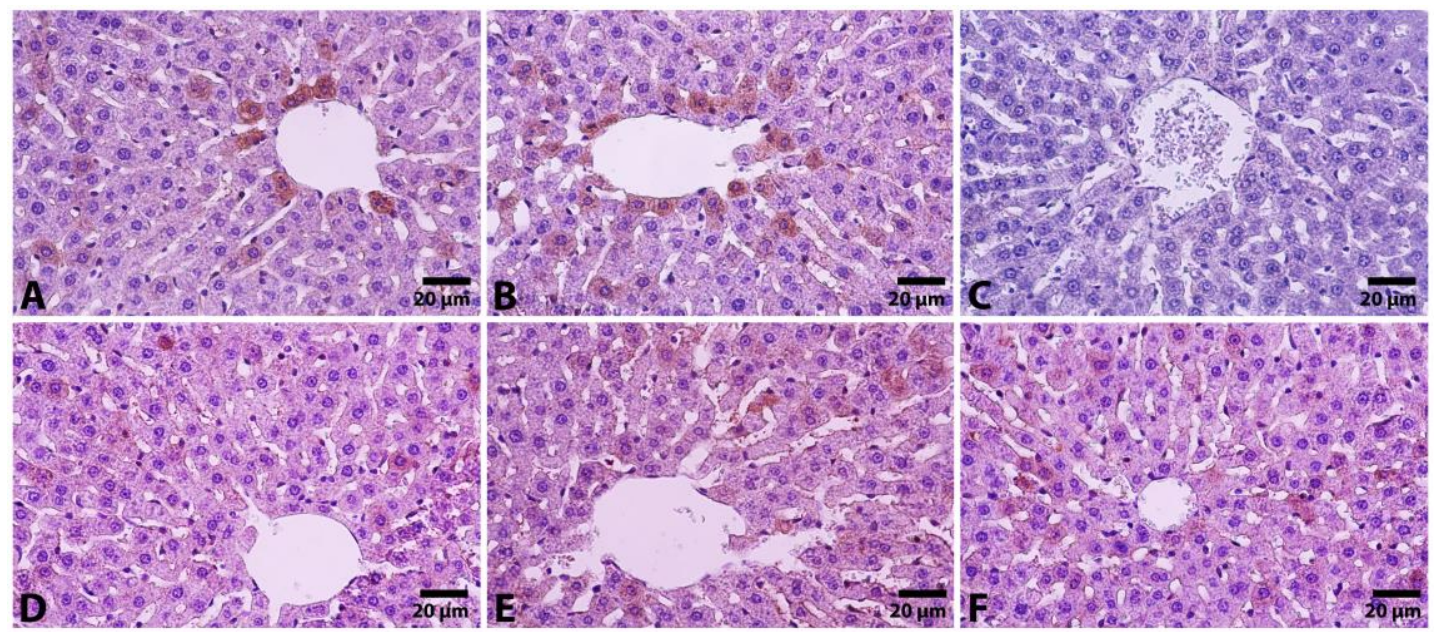

Şekil 4: A: Kontrol, B: Q100, C: Negatif Kontrol, D: CYP, E: Q50+CYP, F: Q100+CYP grubu siçanlara ait karaciğer kesitlerinde Bcl-2 immünpozitifliği. Bar: $20 \mu \mathrm{m}$. 
Canlı vücudunda oluşan lipid peroksidasyonun, dolayısıyla oksidatif stresin, en önemli göstergelerinden biri malondialdehit bileşiğinin (MDA) oluşumudur ${ }^{34-36}$. Akrolein ve lipid peroksidasyonunun bir ürünü olan MDA, çok reaktiftir ve proteinlerin aminoasitleriyle etkileşime girerek enzimlerde hem yapısal hem fonksiyonel değişikliklerin oluşmasına neden olur $^{19}$. Çeşitli ilaçlara ve toksik bileşiklere karşı hücresel duyarlılığın önemli bir göstergesi olan glutatyon (GSH) miktarındaki artış ise bu toksik bileşiklerin öldürücü etkilerine karşı hücrelerin korunması için gereklidir ${ }^{37}$. Çünkü GSH serbest radikallerin temizlenmesini sağlayarak hücreleri oksidatif strese karşı korumada önemli rol oynar ${ }^{38}$. Hücrelerdeki GSH seviyesindeki azalmanın farklı hayvan türlerinde tümör gelişimini teșvik edebileceği de bildirilmektedir ${ }^{39}$. Antioksidan enzimlerden biri olan SOD ise canlıda var olan oksidan antioksidan dengesinin devamı için gereklidir ve hücreleri serbest radikalleri temizlemek suretiyle oksidatif stresten korumada hayati bir öneme sahiptir ${ }^{40}$.

Çeşitli meyve ve sebzelerde bulunan bir flavonoid olan kuersetin bileşiği, oldukça yararlı bir antioksidandır. Bu bileşiğin iskemireperfüzyon hasarında süperoksit süpürücü olduğunu, bakteriyel lipopolisakkarid ile indüklenen oksidatif strese, sekonder biliyer siroza, spontan hipertansiyona karşı koruyucu bir özelliği olduğunu, anjiogenezisi, karsinogenezisi ve portal hipertansif gastropatiyi inhibe ettiğini gösteren çalışmalar mevcuttur ${ }^{41}$. Ayrıca kuersetinin karaciğer fibrozu ve kronik safra yolları tıkanıklı̆̆ı gibi çeşitli hastalıklara karşı da terapötik bir potansiyele sahip olduğu gösterilmiştir ${ }^{42}$.

Yapılan bir çalışmada CYP uygulaması sonucunda MDA, hidrojen peroksit ve nitrit seviyelerinde artışın, GSH seviyesinde ise azalmanın olduğu tespit edilmiștir. MDA, hidrojen peroksit ve nitrit seviyelerindeki artışın, GSH seviyesindeki azalmanın CYP ile indüklenen oksidatif strese bağlı bir sonuç olduğu bildirilmiştir43. Yine aynı şekilde CYP uygulaması ile farelerin karaciğerinde SOD ve GSH seviyelerinde azalma, MDA seviyesinde ise artma tespit edilmiştir ${ }^{44}$. Yaptığımız çalışmada biyokimyasal sonuçlara göre sıçanlara CYP verilmesinin ardından hayvanlardan alınan doku örneklerinde kontrol grubuna kıyasla MDA seviyesinde artışın, GSH ve SOD seviyelerinde ise azalmanın olduğu görüldü. MDA seviyesinde artma, GSH ve SOD seviyelerinde azalma hücresel hasara neden olan serbest radikallere karşı hücresel savunmayı azaltmaktadır. Dolayısı ile çalışmamızda CYP grubunda kontrol grubuna klyasla SOD ve GSH seviyelerinin azalması, MDA seviyesinin artması literatür bilgisiyle uyumludur. CYP uygulamasının neden olduğu hücresel hasarı tamir etmesi beklenen kuersetin verilen gruplarda ise CYP grubuna kıyasla MDA seviyesinde azalma, GSH ve SOD seviyelerinde artma olduğu tespit edildi. $\mathrm{Bu}$ durum da kuersetin bileşiğinin güçlü bir antioksidan özelliğe sahip olduğunu ortaya koymaktadır.

Oksidatif stres sonuçlarını takiben, karaciğer dokusunda histopatolojik ve immunohistokimyasal değerlendirmelere geçildi. Bunun için dokulara uygulanan Crossman'ın modifiye üçlü boyaması ile genel histolojik değerlendirme yapıldı. Yapılan bir çalışmada CYP tedavisi uygulanan ratların karaciğerinde periportal inflamasyon, kanama ve konjesyon gibi patolojik değişiklikler tespit edilmiştir. Bu patolojik değişikliklerin CYP'nin serbest radikal oluşumunu indükleme ve antioksidan savunma sistemini yok etme yeteneği ile ilișkisi olabileceği düşünülmüştür ${ }^{33}$.

Ayrıca CYP'nin akut enflamatuar hücre infiltrasyonuna, kan damarlarının tıkanmasına, fokal nekroz, piknozis ve karyoliz gibi hasarlara neden olduğu da kanıtlanmıștır. Bunlara ek olarak CYP uygulamasinin hepatositlerde dejenerasyona, yağ birikimine, sitoplazmik vakuolizasyona, deforme olmuş safra kanalları 
etrafında hiperproliferasyona, displaziye ve çekirdek hasarına yol açtığı da gösterilmiştir ${ }^{45,46}$. Biz de yapmış olduğumuz Crossman'ın modifiye üçlü boyaması ile CYP grubuna ait kesitlerde sinüzoidal dilatasyon, mononükleer hücre infiltrasyonu, vasküler konjesyon gibi değişiklikler tespit ettik. Görmüş olduğumuz bu değişiklikler literatürle uygunluk göstermekteydi. Kuersetin uygulaması ile de bu hasarlarda düzelme olduğunu tespit ettik.

Caspase-3, Bax, Bcl-2 ve TUNEL boyamaları ile de dokulardaki apoptozis ekspresyonu değerlendirildi. Apoptozis olayının başlıca düzenleyicileri pro-apoptotik proteinlerden Bax, anti-apoptotik proteinlerden Bcl-2'dir. Metotreksat (MTX) ile indüklenmiş olan hepatotoksisite üzerine yapılan bir çalışmada, MTX'in diş mitokondri membranında Bax translokasyonuna neden olduğu, bu durumunda mitokondriyal geçirgenlikte dolayısıyla sitosole doğru sitokrom-c akışında artışa neden olduğu gösterilmiştir ${ }^{47}$. Bu sonuçlar hepatosellüler apoptozis durumunda Bax ve Caspase-3 ekspresyonlarında artışın, Bcl-2 ekspresyonunda ise azalmanın olacağını göstermektedir ${ }^{48,49}$. Yapılan başka bir çalışmada CYP verilen sıçanlara ait karaciğer kesitlerinde TUNEL pozitif hücre sayısının kontrol grubuna kıyasla artış gösterdiği tespit edilmiştir. $\mathrm{Bu}$ hücrelerin sayısındaki artışın, CYP uygulaması ile artan serbest radikallerin etkisiyle meydana gelen oksidatif DNA hasarına bağlı olduğu bildirilmiştir ${ }^{50}$. Biz de yapmış olduğumuz çalışmada CYP uygulayarak hepatotoksisite oluşturduğumuz CYP grubu kesitlerinde kontrol grubuna klyasla Bax ve Caspase-3 ekspresyonlarında artışın olduğunu, Bcl-2 ekspresyonunda ise azalmanın olduğunu gözlemledik. Yine CYP grubunda TUNEL pozitif hücre sayısında artmanın olduğunu tespit ettik. $\mathrm{Bu}$ değişikliklerin kuersetin uygulaması ile kontrol grubuna yakın değerlere döndüğünü de gözlemledik.
Sonuç olarak, mevcut çalışmamızda CYP tedavisinin oksidatif stresle sonuçlandığını ve karaciğerdeki antioksidan sistemi bozduğunu, kuersetin tedavisinin ise antioksidan savunma sistemini güçlendirerek oksidatif stresin etkilerini tersine çevirdiğini tespit ettik. Dolayısıyla kemoterapiyle birlikte kuersetin verilmesinin kemoterapötiklerin karaciğer üzerindeki zararlı etkilerini azaltabileceğini, bu yüzden de birlikte kullanılmalarının faydalı olabileceğini düşünmekteyiz.

Çıkar Çatışması Beyanı: Yazarlar çıkar çatışması olmadığını bildirmişlerdir.

Finansal Destek: $\mathrm{Bu}$ çalışma Atatürk Üniversitesi BAP Yönetim Birimi tarafından 2015/62 nolu proje ile desteklenmiştir.

Declaration of Conflicting Interests: The authors declare that they have no conflict of interest.

Financial Disclosure: This work was supported by Scientific Research Projects Coordination Unit of Ataturk University. Project number 2015/62.

\section{KAYNAKLAR}

1. Nafees S, Rashid S, Ali N, et al. Rutin ameliorates cyclophosphamide induced oxidative stress and inflammation in Wistar rats: role of NFkappaB/MAPK pathway. Chem Biol Interact 2015; 231:98-107.

2. Abd El Tawab AM, Shahin NN, AbdelMohsen MM. Protective effect of Satureja montana extract on cyclophosphamide-induced testicular injury in rats. Chem Biol Interact 2014; 224:196-205.

3. Xie R, Chen L, Wu H, et al. GnRH Antagonist Improves Pubertal Cyclophosphamide-Induced Long-Term Testicular Injury in Adult Rats. Int J Endocrinol 2018; 2018:4272575.

4. Zarei M, Shivanandappa T. Amelioration of cyclophosphamide-induced hepatotoxicity by the root extract of Decalepis hamiltonii in mice. Food Chem Toxicol2013; 57: 179-84.

5. Abraham P, Sugumar E. Increased glutathione levels and activity of PON1 (phenyl acetate esterase) in the liver of rats after a single dose of cyclophosphamide: A defense mechanism? Experimental and Toxicologic Pathology 2008; 59: 301-6. 
6. Bhattacharjee A, Basu A, Biswas J, et al. Nano-Se attenuates cyclophosphamide-induced pulmonary injury through modulation of oxidative stress and DNA damage in Swiss albino mice. Mol Cell Biochem 2015; 405: 243-56.

7. Shulman HM, McDonald GB, Matthews D, et al. An analysis of hepatic venocclusive disease and centrilobular hepatic degeneration following bone marrow transplantation. Gastroenterology 1980; 79: 1178-91.

8. Bacon AM, Rosenberg SA. Cyclophosphamide hepatotoxicity in a patient with systemic lupus erythematosus. Ann Intern Med 1982; 97: 62-3.

9. Snover DC, Weisdorf S, Bloomer J, et al. Nodular regenerative hyperplasia of the liver following bone marrow transplantation. Hepatology 1989; 9: 443-8.

10. Sherif IO. The effect of natural antioxidants in cyclophosphamide-induced hepatotoxicity: Role of Nrf2/HO-1 pathway. Int Immunopharmacol 2018; 61:29-36.

11. Sladek NE. Metabolism of cyclophosphamide by rat hepatic microsomes. Cancer Res 1971; 31: 901-8.

12. Haque R, Bin-Hafeez B, Parvez S, et al. Aqueous extract of walnut (Juglans regia L.) protects mice against cyclophosphamide-induced biochemical toxicity. Hum Exp Toxicol 2003; 22: 473-80.

13. Manda K, Bhatia AL. Prophylactic action of melatonin against cyclophosphamide-induced oxidative stress in mice. Cell Biol Toxicol 2003; 19: 367-72.

14. Stankiewicz A, Skrzydlewska E, Makiela M. Effects of amifostine on liver oxidative stress caused by cyclophosphamide administration to rats. Drug Metabol Drug Interact 2002; 19:67-82.

15. Hamzeh M, Hosseinimehr SJ, Khalatbary AR, et al. Atorvastatin mitigates cyclophosphamide-induced hepatotoxicity via suppression of oxidative stress and apoptosis in rat model. Res Pharm Sci 2018; 13: 440-9.

16. Horton ND, Mamiya BM, Kehrer JP. Relationships between cell density, glutathione and proliferation of A549 human lung adenocarcinoma cells treated with acrolein. Toxicology 1997; 122: 111-22.

17. Mohammad MK, Avila D, Zhang J, et al. Acrolein cytotoxicity in hepatocytes involves endoplasmic reticulum stress, mitochondrial dysfunction and oxidative stress. Toxicol Appl Pharmacol 2012; 265:7382.

18. Pratheeshkumar P, Kuttan G. Ameliorative action of Vernonia cinerea L. on cyclophosphamide-induced immunosuppression and oxidative stress in mice. Inflammopharmacology 2010; 18:197-207.

19. Tripathi DN, Jena GB. Intervention of astaxanthin against cyclophosphamide-induced oxidative stress and DNA damage: a study in mice. Chem Biol Interact 2009; 180:398-406.
20. Patra K, Bose S, Sarkar S, et al. Amelioration of cyclophosphamide induced myelosuppression and oxidative stress by cinnamic acid. Chem Biol Interact 2012; 195: 231-9.

21. Wei X, Su F, Su X, et al. Stereospecific antioxidant effects of ginsenoside Rg3 on oxidative stress induced by cyclophosphamide in mice. Fitoterapia 2012; 83: 636-42.

22. Gibellini L, Pinti M, Nasi M, et al. Quercetin and cancer chemoprevention. Evid Based Complement Alternat Med 2011; 2011:591356.

23. Chen KC, Hsu WH, Ho JY, et al. Flavonoids Luteolin and Quercetin Inhibit RPS19 and contributes to metastasis of cancer cells through c-Myc reduction. J Food Drug Anal 2018; 26: 1180-91.

24. Kahraman A, Erkasap N, Koken $\mathrm{T}$, et al. The antioxidative and antihistaminic properties of quercetin in ethanol-induced gastric lesions. Toxicology 2003; 183: 133-42.

25. Olayinka ET, Ore A, Ola OS, et al. Protective effect of quercetin on melphalan-induced oxidative stress and impaired renal and hepatic functions in rat. Chemother Res Pract 2014; 2014:936526.

26. Ong CS, Tran E, Nguyen TT, et al. Quercetin-induced growth inhibition and cell death in nasopharyngeal carcinoma cells are associated with increase in Bad and hypophosphorylated retinoblastoma expressions. Oncol Rep 2004; 11:727-33.

27. Seufi AM, Ibrahim SS, Elmaghraby TK, et al. Preventive effect of the flavonoid, quercetin, on hepatic cancer in rats via oxidant/antioxidant activity: molecular and histological evidences. J Exp Clin Cancer Res 2009; 28:80.

28. Kumar Mishra S, Singh P, Rath SK. Protective effect of quercetin on chloroquine-induced oxidative stress and hepatotoxicity in mice. Malar Res Treat 2013; 2013:141734.

29. Dong YS, Wang JL, Feng DY, et al. Protective effect of quercetin against oxidative stress and brain edema in an experimental rat model of subarachnoid hemorrhage. Int J Med Sci 2014; 11: 282-90.

30. Tripathi DN, Jena GB. Astaxanthin intervention ameliorates cyclophosphamide-induced oxidative stress, DNA damage and early hepatocarcinogenesis in rat: role of Nrf2, p53, p38 and phase-II enzymes. Mutat Res 2010; 696:69-80.

31. Habibi E, Shokrzadeh M, Ahmadi A, et al. Pulmonoprotective Action of Zataria multiflora Ethanolic Extract on Cyclophosphamide-Induced Oxidative Lung Toxicity in Mice. Chin J Integr Med 2018.

32. Kehrer JP, Biswal SS. The molecular effects of acrolein. Toxicol Sci 2000; 57:6-15. 
33. Oyagbemi AA, Omobowale OT, Asenuga ER, et al. Cyclophosphamide-induced Hepatotoxicity in Wistar Rats: The Modulatory Role of Gallic Acid as a Hepatoprotective and Chemopreventive Phytochemical. Int J Prev Med 2016; 7:51.

34. Tabakoğlu E DR. Veteriner Hekimlikte Oksidatif Stres ve Bazı Önemli Hastalıklarda Oksidatif Stresin Etkileri. AVKAE Derg 2013; 3:69-75.

35. Cavdaroğlu BK, N. Başkol, G. Demir, H. Postmenopozal osteoporozlu hastalarda proteinler ve lipidlerdeki oksidatif stresin değerlendirilmesi. Dicle Tip Dergisi 2014; 41:71-77.

36. Guo TZ, Wei T, Huang TT, et al. Oxidative Stress Contributes to Fracture/Cast-Induced Inflammation and Pain in a Rat Model of Complex Regional Pain Syndrome. J Pain 2018; 19: 1147-56.

37.SheweitaSA. Drug-metabolizingenzymes: mechanisms and functions. Curr Drug Metab 2000; 1: 107-32.

38. Townsend DM, Tew KD, Tapiero H. The importance of glutathione in human disease. Biomed Pharmacother 2003; 57: 145-55.

39. Murray GI, Burke MD, Ewen SW. Glutathione localisation in benign and malignant human breast lesions. Br J Cancer 1987; 55: 605-9.

40. Cui H, Li T, Wang L, et al. Dioscorea bulbifera polysaccharide and cyclophosphamide combination enhances anti-cervical cancer effect and attenuates immunosuppression and oxidative stress in mice. Sci Rep 2016; 5:19185.

41. Kanter M, Tuncer I, Erboga M, et al. The effects of quercetin on liver regeneration after liver resection in rats. Folia Morphol (Warsz) 2016; 75: 179-87.
42. de David C, Rodrigues G, Bona S, et al. Role of quercetin in preventing thioacetamide-induced liver injury in rats. Toxicol Pathol 2011; 39: 949-57.

43. Santra A, Chowdhury A, Chaudhuri S, et al. Oxidative stress in gastric mucosa in Helicobacter pylori infection. Indian J Gastroenterol 2000; 19: 21-3.

44. Tripathi P, Patel RK, Tripathi R, et al. Investigation of antigenotoxic potential of Syzygium cumini extract (SCE) on cyclophosphamide-induced genotoxicity and oxidative stress in mice. Drug Chem Toxicol 2013; 36:396-402.

45. Mahmoud AM, Al Dera HS. 18beta-Glycyrrhetinic acid exerts protective effects against cyclophosphamideinduced hepatotoxicity: potential role of PPARgamma and Nrf2 upregulation. Genes Nutr 2015; 10:41.

46. Li X, Li B, Jia Y. The Hepatoprotective Effect of Haoqin Qingdan Decoction against Liver Injury Induced by a Chemotherapeutic Drug Cyclophosphamide. Evid Based Complement Alternat Med 2015; 2015:978219.

47. Mukherjee S, Ghosh S, Choudhury S, et al. Pomegranate reverses methotrexate-induced oxidative stress and apoptosis in hepatocytes by modulating Nrf2-NF-kappaB pathways. J Nutr Biochem 2013; 24: 2040-50.

48. El-Agamy DS, Abo-Haded HM, Elkablawy MA. Cardioprotective effects of sitagliptin against doxorubicin-induced cardiotoxicity in rats. Exp Biol Med (Maywood) 2016; 241: 1577-87.

49. Marques C, Mega C, Goncalves A, et al. Sitagliptin prevents inflammation and apoptotic cell death in the kidney of type 2 diabetic animals. Mediators Inflamm 2014; 2014:538737.

50. Saandeep K, Vikram A, Tripathi DN, et al. Influence of hyperglycaemia on chemical-induced toxicity: study with cyclophosphamide in rat. Basic Clin Pharmacol Toxicol 2009; 105: 236-42. 